\title{
Assessing the Accuracy of Information and User Ease of the Expert Application System Based on User Satisfaction
}

\author{
Andri Permana Wicaksono ${ }^{1, *}$ Demiawan Rachmatta Putro Mudiono ${ }^{2,}$, Indah \\ Muflihatin $^{3}$ \\ ${ }^{1,2.3}$ Department of Health, Politeknik Negeri Jember, Indonesia \\ *Corresponding author. Email: andri_permana@polije.ac.id
}

\begin{abstract}
This study assessed the application of an expert system for hepatitis disease based on user satisfaction assessment. The purpose of this study is to assess the accuracy of the information and the ease of users of the existing system on the hepatitis expert system application. This type of research is a quantitative descriptive study with a cross-sectional approach. This research is described in descriptive analysis and multiple linear regression analysis. The descriptive results on the accuracy of the information have a mean value of 2.99 and user convenience with a mean of 3.39. While the results of multiple linear regression analysis indicate that the accuracy of the information does not have a significant effect on user satisfaction, the ease of use shows a significant effect on user satisfaction.
\end{abstract}

Keywords: expert system application, information accuracy, user convenience, user satisfaction.

\section{INTRODUCTION}

The field of public health informatics has supported countries experiencing recent disasters to develop and implement real-time reporting, transmission and dissemination of epidemiological data for rapid detection, verification, and public health action. [1].

Indonesia is one of the tropical countries with a high number of patients with hepatitis cases, in 2018 there were 1,017,290 cases of hepatitis found in Indonesia. [2]. Rapid detection and rapid response to disease and epidemics are essential during humanitarian disasters, especially in countries with poor disease control mechanisms. Public health surveillance systems are compromised or overwhelmed to meet the needs of humanitarian emergencies, including the timeliness and high quality of data

A disease warning or early detection system is a health facility-based disease early detection system that uses electronic tools and platforms for effective collection, management, analysis, and visualization of data using mobile.

There are several Android-based warning systems or early detection of hepatitis disease in Indonesia, one of which is the Hepatitis Disease Expert System (SIMPATI) application. The SIMPATI application has been operating for one year but the evaluation process in user satisfaction has never been carried out. [3].

This satisfaction evaluation is used as an assessment process on applications that look at the accuracy of the information and the ease of system users.

\section{RESEARCH METHOD}

This type of research uses quantitative research with a cross-sectional approach. The sample used was 60 people who used the SIMPATI application. Sampling using simple random sampling technique where the entire population has the same opportunity and is free to be selected as a sample member because it has the same characteristics. More information is presented in Table 1 below. 
Table 1 Operational definition

\begin{tabular}{|c|c|c|c|c|c|}
\hline Variable & $\begin{array}{l}\text { Operational } \\
\text { definition }\end{array}$ & $\begin{array}{l}\text { Meas } \\
\text { uring } \\
\text { instr } \\
\text { ume } \\
\text { nt }\end{array}$ & $\begin{array}{l}\text { how } \\
\text { to } \\
\text { meas } \\
\text { ure }\end{array}$ & $\begin{array}{l}\text { measureme } \\
\text { nt result }\end{array}$ & $\begin{array}{l}\text { data } \\
\text { scale }\end{array}$ \\
\hline \multicolumn{6}{|c|}{ Dependent variable } \\
\hline $\begin{array}{l}\text { User } \\
\text { satisf } \\
\text { actio } \\
\mathrm{n}(\mathrm{Y})\end{array}$ & $\begin{array}{l}\text { How far are users } \\
\text { satisfied and believe } \\
\text { in the information } \\
\text { system provided to } \\
\text { meet the needs of } \\
\text { respondents? }\end{array}$ & $\begin{array}{l}\text { Quest } \\
\text { ionnai } \\
\text { re }\end{array}$ & $\begin{array}{l}\text { Respond } \\
\text { ents } \\
\text { filled out } \\
\text { the } \\
\text { question } \\
\text { naires } \\
\text { that the } \\
\text { researche } \\
\text { rs gave } \\
\text { themselv } \\
\text { es. }\end{array}$ & $\begin{array}{l}\text { The } \\
\text { user } \\
\text { satisfa } \\
\text { ction } \\
\text { variabl } \\
\text { e was } \\
\text { measu } \\
\text { red by } \\
\text { a five- } \\
\text { point } \\
\text { Likert } \\
\text { scale. }\end{array}$ & $\begin{array}{l}\text { ordin } \\
\text { al }\end{array}$ \\
\hline \multicolumn{6}{|c|}{ Independen } \\
\hline $\begin{array}{l}\text { Accu } \\
\text { racy } \\
\text { Infor } \\
\text { mati } \\
\text { on } \\
(\mathrm{X} 1)\end{array}$ & $\begin{array}{l}\text { Accuracy in } \\
\text { producing the } \\
\text { information needed } \\
\text { by respondents. }\end{array}$ & $\begin{array}{l}\text { Quest } \\
\text { ionnai } \\
\text { re }\end{array}$ & $\begin{array}{l}\text { Respond } \\
\text { ents } \\
\text { filled out } \\
\text { the } \\
\text { question } \\
\text { naires } \\
\text { that the } \\
\text { researche } \\
\text { rs gave } \\
\text { themselv } \\
\text { es. }\end{array}$ & $\begin{array}{l}\text { The } \\
\text { variabl } \\
\text { e } \\
\text { accura } \\
\text { cy was } \\
\text { measu } \\
\text { red by } \\
\text { a five- } \\
\text { point } \\
\text { Likert } \\
\text { scale. }\end{array}$ & $\begin{array}{l}\text { ordin } \\
\text { al }\end{array}$ \\
\hline $\begin{array}{l}\text { Ease } \\
\text { Of } \\
\text { Use } \\
\text { (X2) }\end{array}$ & $\begin{array}{l}\text { The ease that users } \\
\text { feel when the system } \\
\text { is used starts from } \\
\text { the data entry } \\
\text { process, processing } \\
\text { data and finding the } \\
\text { required } \\
\text { information. }\end{array}$ & $\begin{array}{l}\text { Quest } \\
\text { ionnai } \\
\text { re }\end{array}$ & $\begin{array}{l}\text { Respond } \\
\text { ents } \\
\text { filled out } \\
\text { the } \\
\text { question } \\
\text { naires } \\
\text { that the } \\
\text { researche } \\
\text { rs gave } \\
\text { themselv } \\
\text { es. }\end{array}$ & $\begin{array}{l}\text { The } \\
\text { Ease } \\
\text { of Use } \\
\text { variabl } \\
\text { e was } \\
\text { measu } \\
\text { red } \\
\text { with a } \\
\text { five- } \\
\text { point } \\
\text { Likert } \\
\text { scale. }\end{array}$ & $\begin{array}{l}\text { ordin } \\
\text { al }\end{array}$ \\
\hline
\end{tabular}

Simple Regression Analysis is intended to determine the effect of the independent variable on the dependent variable [1].

\section{RESULTS AND DISCUSSION}

\subsection{Results}

Descriptive analysis is used to provide an overview of the indicators in the variables in the study. In this descriptive analysis, an analysis of the interpretation of scores from respondents' responses to each variable indicator was carried out based on the average value.

Table 2 Results of Respondents' Responses to Accuracy Information Variables

\begin{tabular}{|c|c|c|c|c|}
\hline No. & Variable & \multicolumn{2}{|c|}{ Respondent's Answer } & \multirow{2}{*}{ Mean } \\
\cline { 3 - 4 } & Indicator & Minimum & Maximum & \\
\hline 1. & X2_1 & 1 & 5 & 3,13 \\
\hline 2. & X2_2 & 1 & 4 & 2,37 \\
\hline 3. & X2_3 & 2 & 5 & 3,43 \\
\hline 4. & X2_4 & 1 & 4 & 3,07 \\
\hline 5. & X2_5 & 1 & 4 & 2,97 \\
\hline \multicolumn{4}{|c|}{$\begin{array}{r}\text { The average overall response of } \\
\text { respondents }\end{array}$} \\
\hline \multicolumn{4}{|c}{} \\
\hline
\end{tabular}

From the overall average of respondents' responses to the accuracy variable, the mean value is 2.99 so it is included in the quite satisfied category, thus it can be concluded that respondents are quite satisfied with the accuracy of the hepatitis expert system application. This shows that the application has both positive and negative sides, resulting in sufficient satisfaction with accuracy. The positive side is that respondents think that the information produced by the application is very accurate, but there is still a negative side, namely the application often experiences errors when used.

Table 3 Results of Respondents' Responses to Ease of Use Variables

\begin{tabular}{|c|c|c|c|c|}
\hline No. & Variable & \multicolumn{2}{|c|}{ Respondent's Answer } & \multirow{2}{*}{ Mean } \\
\cline { 3 - 4 } & Indicator & Minimum & Maximum & \\
\hline 1. & X4_1 & 1 & 5 & 3,65 \\
\hline 2. & X4_2 & 1 & 5 & 3,17 \\
\hline 3. & X4_3 & 2 & 4 & 3,53 \\
\hline 4. & X4_4 & 1 & 4 & 3,25 \\
\hline 5. & X4_5 & 1 & 5 & 3,38 \\
\hline \multicolumn{4}{|c|}{$\begin{array}{r}\text { The average overall response of } \\
\text { respondents }\end{array}$} \\
\hline \multicolumn{5}{|c}{} \\
\hline
\end{tabular}

From the overall average of respondents' responses to the ease of use variable, the mean value of 3.39 was obtained so that it was included in the quite satisfied category, thus it can be concluded that respondents were quite satisfied with the ease of use of the hepatitis expert system application. This shows that the application has both positive and negative sides, resulting in sufficient satisfaction with the ease of use. The positive side is that respondents think that the application is very easy to use (user-friendly), but there is still a negative side, namely the respondent thinks that the application does not provide a help menu.

Table 4 Multiple regression results table

\begin{tabular}{|c|c|c|c|c|c|}
\hline \multirow{2}{*}{ Model } & \multicolumn{2}{|c|}{$\begin{array}{c}\text { Unstandardized } \\
\text { Coefficients }\end{array}$} & $\begin{array}{c}\text { Standardized } \\
\text { Coefficients }\end{array}$ & \multirow{2}{*}{ t } & \multirow{2}{*}{ Sig. } \\
\cline { 2 - 5 } & B & $\begin{array}{c}\text { Std. } \\
\text { Error }\end{array}$ & Beta & & \\
\hline Accuracy $(\mathrm{X} 1)$ & 0,055 & 0,042 & 0,130 & 1,324 & 0,191 \\
\hline
\end{tabular}




\begin{tabular}{|l|l|l|l|l|l|}
\hline $\begin{array}{l}\text { Ease of Use } \\
(\mathrm{X} 2)\end{array}$ & 0,193 & 0,087 & 0,226 & 2,220 & 0,031 \\
\hline
\end{tabular}

The partial test results in table 4 show the regression coefficient between the accuracy variable and the user satisfaction variable for the hepatitis expert system application of 0.055 with a t-count value of 1.324 . Because the significance probability $\mathrm{t}$ value is 0.191 , which is greater than the 0.05 significance level, there is no effect between accuracy and user satisfaction of the hepatitis expert system application.

In addition to that, the partial test results in table 4 show that the regression coefficient between the format variable and the user satisfaction variable for the hepatitis expert system application is 0.193 with a tcount value of 2,220 . Therefore, the significance probability $\mathrm{t}$ value is 0.031 which is smaller than The significance level of 0.05 means an influence between the format variables on user satisfaction of the hepatitis expert system application.

\subsection{Discussion}

The partial test results for the first hypothesis indicate that the accuracy variable does no effect on user satisfaction of the hepatitis expert system application. This is indicated by the value of the significance probability $\mathrm{t}$, which is greater than 0.05 , thus the first hypothesis is rejected. This means that there is no influence between the accuracy variables on application user satisfaction. The results of this study are not the same as the results of research conducted by [1] which states that the accuracy variable affects the satisfaction of core banking system users at Bank $\mathrm{ABC}$ and research conducted by [1] which states that the accuracy variable affects the accounting software user satisfaction

Based on the respondents' responses, although respondents think that the information generated by the application is accurate, this study cannot prove the influence of the accuracy variable on user satisfaction. This is because, in reality, related to data input, respondents in inputting data are still incomplete what is requested by the application so that the accuracy of early detection of hepatitis is less accurate. If there has been incomplete data at the beginning of input, then the information generated by the application can be said to be inaccurate. Another possibility is that the expert system calculations still contain errors because there are still misses in the information generated. In addition, users search for the information they need mostly only from the website, not from the application, which means that in searching for data they are still not fully using the application. So in this study, the accuracy variable does no effect on application user satisfaction. However, if in the future you use the application thoroughly and no longer rely on other applications or websites, the accuracy of the information generated by the application is very much needed by users, especially the health department who uses information from the application for decision making.

The results of the partial test (t-test) for the second hypothesis indicate that the ease of use variable affects application user satisfaction. This is indicated by the value of the significance probability $t$, which is less than 0.05 , thus both are accepted. This means that there is an influence between the ease of use variables on application user satisfaction. The value of the regression coefficient between the ease of use variable and user satisfaction is positive $(0,193)$, this indicates that the ease of use variable has a positive effect on application user satisfaction. This means that if the ease of use variable is high, the application user satisfaction will be high, otherwise, if the ease of use variable is low, the application user satisfaction will be low as well. In other words, if the ease of use variable in the application is increased, user satisfaction will increase. The results of this study are the same as the results of research conducted by [1] which states that the ease of use variable affects the satisfaction of core banking system users at ABC Bank but is not the same as the results of research conducted by [1] which states that the ease of use variable does not affect the satisfaction of users of accounting software

Based on respondents' responses which stated that ease of use affected satisfaction, it could be because respondents felt that the application was a new thing, so respondents needed time to adjust from selfexamination through the laboratory to self-examination through technology, namely using applications. Another possibility is that some respondents still find it difficult to use the application, especially for middle-aged users. This makes respondents tend to be reluctant to use the application so that it can indirectly affect user satisfaction. This can be overcome using periodic system repairs to attract system users' interest in operating the system. This statement can be corroborated by research that [4] when the Jombang Health Service often makes improvements to the Jombang SIMPUS, the more useful the SIMPUS is for users so that the Jombang SIMPUS is always accepted in its application. The quality of the system is also very influential on user interest. If the system that is built is not suitable for the results of the information needed by system users, it will have an impact on user satisfaction [5].

\section{CONCLUSION}

The assessment of application user satisfaction based on the accuracy variable states that respondents are quite satisfied with the accuracy of the hepatitis expert system application. While the assessment of application user satisfaction based on the ease of use variable stated that 
respondents were quite satisfied with the ease of use of the hepatitis expert system application

\section{ACKNOWLEDGMENTS}

Thank you to those who had supported this research, especially the users of the hepatitis expert system.

\section{REFERENCES}

[1] A. Hosny, C. Parmar, J. Quackenbush, L. H. Schwartz, H. J. W. L. Aerts, and H. H. Edu, "Artificial intelligence in radiology," Nat Rev Cancer, vol. 18, no. 8, pp. 500-510, 2018, doi: 10.1038/s41568-018-0016-5.

[2] P. F. Aprilliani and H. Mustafidah, "Implementasi Certainty Factor Pada Diagnosa Penyakit Infeksi Tropis," J. Ris. Sains dan Teknol., vol. 1, no. 1, pp. 22-36, 2017.

[3] A. P. Wicaksno and D. R. P. Mudiono, "Early Detection of Hepatitis by Using Certainty Factor," vol. 514, no. Icoship 2020, pp. 93-97, 2021, doi: 10.2991/assehr.k.210101.021.

[4] M. C. Roziqin, D. R. P. Mudiono, and N. Amalia, "Analisis Penerimaan Simpus Ditinjau dari Persepsi Pengguna di Puskesmas Mojoagung dengan Metode TAM. Jurnal Teknologi Informasi dan Ilmu Komputer, 8(1).," J. Teknol. Inf. dan Ilmu Komput., vol. 8, no. 1, pp. 47-54, 2021, doi: 10.25126/jtiik.202182907.

[5] Mudiono, "Dampak Kualitas Sistem , Pengguna Sistem dan Organisasi dalam Pemanfaatan Kinerja Sistem Informasi Manajemen Rumah Sakit di RSU Dr . H . Koesnadi Bondowoso (Impact of System Quality , System Users and Organization in Utilization of Hospital Information Ma," Multidiscip. J., vol. 589, no. 1, pp. 25-29, 2018. 